\title{
Peculiarities of the effect of secondary amines with cyclic substituents on microbial steel corrosion
}

\section{I.M. Kurmakova, ${ }^{1} *$ O.S. Bondar, ${ }^{1}$ V.I. Vorobyova, ${ }^{2}$ M.I. Skiba, ${ }^{3}$ S.V. Tkachenko ${ }^{1}$ and O.P. Makey ${ }^{1}$}

\author{
${ }^{1}$ T.H. Shevchenko National University "Chernihiv Colehium”, 53 Hetmana Polubotka str., \\ Chernihiv, 14013, Ukraine \\ ${ }^{2}$ National Technical University of Ukraine "Igor Sikorsky Kyiv Polytechnic Institute", \\ 37 Peremohy Ave, Kyiv, 03056 Ukraine \\ ${ }^{3}$ Ukrainian State University of Chemical Technology, ave. Gagarin, 8, 49005, Dnipro, \\ Ukraine \\ *E-mail: kurmakova@mail.ru
}

\begin{abstract}
The effect of secondary amines with cyclic substituents (triazoloazepine, unsubstituted phenyl or substituted phenyl ones) on the microbial corrosion of low-carbon steel induced by sulfatereducing bacteria isolated from various technogenic media was studied. The compounds were obtained by reactions of 7-methoxy-3,4,5,6-tetrahydro- $2 \mathrm{H}$-azepine with hydrazides of substituted $N$-arylaminoacetic acids. It was found by gravimetric and electrochemical methods that secondary amines with $p$-methoxyphenyl and $p$-chlorophenyl substituents hinder steel corrosion in the neutral Postgate "B" water-salt medium, both in the presence of enrichment bacterial culture and the Desulfovibrio sp. M.4.1 strain. The highest inhibitive effect (a 2.13fold corrosion rate decrease) is shown by the compound with the $p$-chlorophenyl substituent. It has been shown that the effect of concentration within $0.5-2.0 \mathrm{~g} / \mathrm{l}$ on the efficiency of biocorrosion inhibition is insignificant. The results obtained were explained by the antimicrobial action of secondary amines on sulfate-reducing bacteria and their satellites (ironreducing and denitrifying bacteria). Using energy dispersive spectroscopy, it has been shown that secondary amines studied can be adsorbed adsorb on mild steel surface under conditions of microbial corrosion in a water-salt medium with bacterial sulfate reduction. The surface layers were found to contain nitrogen contained in the elementary composition of the compounds, as well as chlorine in the case of the secondary amine with the $p$-chlorophenyl substituent. It has been found that the biofilm (a polymeric matrix consisting of bacterial excrements and corrosion products) is formed atop the film of adsorbed compounds. The inhibition effect is ensured only upon adsorption of compounds with antimicrobial properties toward sulfate-reducing bacteria. If secondary amines have no antimicrobial properties toward sulfate-reducing bacteria, iron sulfides are formed on the metal surface and microbial corrosion is accelerated.
\end{abstract}

Key words: biocorrosion, sulfate-reducing bacteria, steel, secondary amine. 


\section{Introduction}

Nowadays the search of the substances with the inhibitor-biocide properties, which can prevent microbial corrosion, is relevant. Besides the problem of increasing the effectiveness of anti-corrosion protection, it is necessary to renew the assortment of inhibitors-biocides periodically. Such inhibitors have practical value in oil and gas industry, closed heat supply networks etc. The decrease of inhibitors-biocides protection efficiency in time is connected with the ability of microorganisms to adapt to the effect of antimicrobial substances [1].

New inhibitors-biocides are developed and studied by T.A. Onat [2], S.M. Beloglazov [3], A.N. Zavershynskii, V.I. Vygdorovych [4, 5], N.M. Agaev [6] and others. We have also suggested a number of effective inhibitors-biocides for the inhibition of mild steel corrosion under the bacterial sulfate-reduction [7, 8]. Out of all compounds, particular attention should be paid to secondary amines with the replaced phenyl and triazoloazepine substituents, which are multifunctional inhibitors. It has been demonstrated $[9,10]$ that during biocorrosion inhibition the effectiveness of the stated compounds depends on the nature and location of the substituent in the benzene nucleus. However, the mechanism of their action is yet to be studied.

The aim of this paper is to study the ability of the secondary amines with the cyclic substituents to adsorb on the mild steel surface under microbial corrosion and study the peculiarities of their action in the media with bacterial sulfate-reduction.

\section{Experimental}

\subsection{Chemicals and organisms}

The substances studied were secondary amines $-N$-aryl- $N-(6,7,8,9$-tetrahydro-5H-[1,2,4]triazolo-[4,3-a]azepin-3-ylmethyl)-amines with the substituent $(\boldsymbol{I})$, and with substituents in the para-position of the benzene nucleus $(\boldsymbol{I I}, \boldsymbol{I I I})$.

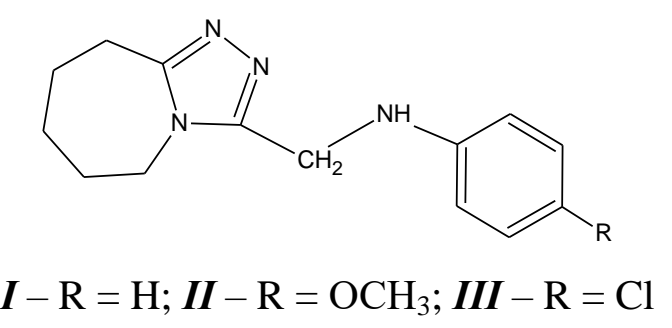

The compounds were obtained [11] with the help of interaction between 7-metoxy3,4,5,6-tetrahydro- $2 \mathrm{H}$-azepine and the hydrazides of substituted $\mathrm{N}$-arylaminoacetic acids. The structure of the compounds was confirmed by elemental analysis and ${ }^{1} \mathrm{H}$ NMR spectroscopy (Bruker-300). The purity of the compounds was confirmed with combined gas chromatography (LC/MSD) method on the Agilent 1200 device with massspectrometry detector Mass Quad G1956B (Agilent Technologies inc.) with positive and negative ionization. 
The enrichment cultures of suphate-reducing bacteria (SRB) with satellites, gathered from the natural man-caused environment [12] and strain Desulfovibrio sp. M.4.1 [13], gathered from the enrichment culture, were used to model the conditions of microbial corrosion. The enrichment culture consisted of: sulfate-reducing bacteria $\left(10^{7}-10^{9} \mathrm{cell} / \mathrm{ml}\right)$, iron-reducing bacteria $\left(10^{6}-10^{8} \mathrm{cell} / \mathrm{ml}\right)$, denitrifying bacteria $\left(10^{5}-10^{6} \mathrm{cell} / \mathrm{ml}\right)$, and ammonifying bacteria $\left(10^{6}-10^{7} \mathrm{cell} / \mathrm{ml}\right)$. The number of the microorganisms in the enrichment culture was evaluated using the Most Probable Number method inoculated to the correspondent liquid selective media: sulfate-reducing bacteria - to Postgate "B" medium, iron-reducing bacteria (IRB) to the Kalinenko medium, denitrifying bacteria (DNB) to Giltay medium, and ammonifying bacteria (AMB) to meat peptone broth [14].

\subsection{Corrosion measurements}

The corrosion tests were performed with the help of gravimetric and electrochemical methods [15].

Model medium Postgate "B" [16] with culture of SRB was used as a testing corrosive medium. This medium is optimal for SRB growth and does not suppress the growth of its satellites in case of enrichment culture. Postgate " $\mathrm{B}$ " medium, composition per liter: $\mathrm{KH}_{2} \mathrm{PO}_{4}-0.5 \mathrm{~g} ; \mathrm{NH}_{4} \mathrm{Cl}-1.0 \mathrm{~g} ; \mathrm{CaSO}_{4} \cdot 2 \mathrm{H}_{2} \mathrm{O}-1.0 \mathrm{~g} ; \mathrm{MgSO}_{4}-2.0 \mathrm{~g}$; calcium lactate $3.5 \mathrm{~g}$; yeast extract $(5 \%)-10 \mathrm{ml} ; \mathrm{FeSO}_{4} \cdot 7 \mathrm{H}_{2} \mathrm{O}(5 \%$ solution in $1 \% \mathrm{HCl})-10 \mathrm{ml}$; ascorbic acid $(5 \%)-2 \mathrm{ml} ; \mathrm{NaHCO}_{3}(5 \%)$ - to $\mathrm{pH} 7.5$. The acidity was measured with a $\mathrm{pH} / \mathrm{ION}$ 340i pH-meter/ionomer.

Subculture concentration was $10 \%$ of the medium volume, number of SRB in the subculture was $10^{9}$ cell $/ \mathrm{ml}$.

The mild steel St3ps coupons (surface area $0.002 \mathrm{~m}^{2}$ ), polished to the $4-5$ class of finish, were used for the gravimetric testing. Before being placed in the corrosive medium, the steel coupons were cleaned with acetone, and weighed with analytical scales accurate to $5 \cdot 10^{-5} \mathrm{~g}$. Coupons exposure time was 10 days at $300 \mathrm{~K}$. Inhibitor concentration was 0.5 and $2 \mathrm{~g} / \mathrm{l}$.

Corrosion rate with or without the inhibitors was calculated with the help of the formula:

$$
k=\Delta m /(S \cdot \tau),
$$

where $\Delta m$ - weight loss in $\mathrm{g} ; S$ - area in $\mathrm{m}^{2} ; \tau$ - exposure time in hours. Corrosion inhibition coefficient was calculated with the help of the formula:

$$
\gamma=k / k^{\prime}
$$

where, $k$ and $k^{\prime}$ are the corrosion rates without and with the inhibitor. The inhibition efficiency (IE) was calculated using the following equation:

$$
\mathrm{IE}=(1-1 / \gamma) \cdot 100 \%
$$


Electrochemical tests [15] were performed with the help of a PI-50-1.1 potentiostat and a PR-8 programmer. In this test a cylindrical steel electrode made of St3ps steel, which had been molded into Teflon casing, was used. The preparation of the electrode surface to the testing included polishing, washing with distilled water and with the studied solution. Three-electrode cell with the separated cathode and anode scope was used. Polarization curves were measured from the potential of free corrosion to $-0.85 \mathrm{~V}$ and from $-0.85 \mathrm{~V}$ to $0.0 \mathrm{~V}$. A silver/silver chloride electrode $(E=0.22 \mathrm{~V})$ was used as the reference electrode, which was connected to the steel electrode with the help of an electrolytic bridge and a Luggin capillary. A platinum auxiliary electrode was used. The electrode potentials provided in the paper were recalculated to the standard hydrogen electrode. The results are presented as data curves of the correlation between the voltage $(E, V)$ and current density $\operatorname{logarithm}\left(\lg i\left(i, \mathrm{~A} / \mathrm{m}^{2}\right)\right)$.

The experiments were conducted in triplicate; the arithmetic mean and standard deviation were calculated with the help of Microsoft Excel.

\subsection{ORP measurements}

The redox potential $(E, \mathrm{mV})$ of the corrosive medium was determined using the oxidationreduction potential sensor and a LabQuest 2 recording device (Vernier Software \& Technology). A silver/silver chloride reference electrode was used. The measurement error was $\pm 0.5 \mathrm{mV}$.

\subsection{Microbiology measurements}

The biocidal activity of compounds against the SRB, IRB, and DNB cultures was studied with the help of the agar diffusion test. Sterile filter paper disks, impregnated with the $2 \%$ alcohol solutions of secondary amines, were used.

The concentration of biogenic hydrogen sulfide was measured with iodometric titration.

\subsection{Scanning electron microscope (SEM)}

The surface analysis of the biofilm, formed on metal samples surface, was performed with scanning electron microscope (SEM). To fix the grown biofilm to the steel surface, the coupons were immersed for $1 \mathrm{~h}$ in a $2 \%$ glutaraldehyde solution, successively dehydrated with 4 ethanol solutions (15 min each) with volume concentrations of $25 \%, 50 \%, 75 \%$ and $100 \%$, and air dried overnight [17]. After fixation, the coupons were examined using field emission scanning electron microscopy FEIE-SEM XL 30. The electron microscopic pictures were taken in the secondary electrons mode. Maximum residual pressure in the microscope column was no more than $6.7 \cdot 10^{-4} \mathrm{~Pa}$ under the gun current of $76 \mathrm{~mA}$. 


\section{6. $X$-ray diffraction $(X R D)$}

Energy dispersive spectrum (EDS) was used to analyze the elemental composition of corrosion products. Before EDS (X-max 50, Japan) analysis of the biofilms and corrosion products, the coupons were pretreated by being soaked in a phosphate buffer solution containing $2.5 \%(\mathrm{w} / \mathrm{w})$ glutaraldehyde for $8 \mathrm{~h}$ in order to immobilize the biofilms to the coupon surface. Afterwards, all the coupons were dried with a nitrogen gas stream and placed in desiccators. The composition of corrosion products on the coupon was analyzed by X-ray diffraction (XRD). XRD patterns were recorded by a diffractometer between 10 and $90^{\circ} \mathrm{C}-2 \theta$ with $\mathrm{Cu} \mathrm{K} \alpha$ radiation at a rating of $40 \mathrm{kV}, 20 \mathrm{~mA}$.

\section{Results and discussion}

Microbial St3ps steel corrosion in the medium with SRB enrichment culture proceeds at a rate of $16.00 \cdot 10^{-3} \mathrm{~g} \cdot \mathrm{m}^{-2} \cdot$ hour $^{-1}$ (Table 1 ).

Table 1. Effect of secondary amines on microbial St3ps steel corrosion in Postgate "B" medium (compounds concentration $2 \mathrm{~g} / \mathrm{l}$ ).

\begin{tabular}{|c|c|c|c|c|c|c|}
\hline \multirow[t]{2}{*}{ Compound } & \multicolumn{3}{|c|}{ Enrichment culture } & \multicolumn{3}{|c|}{ Strain Desulfovibrio sp. M.4.1 } \\
\hline & $k \cdot 10^{3}, \mathrm{~g} \cdot \mathrm{m}^{-2} \cdot \mathbf{h}^{-1}$ & $\gamma$ & IE, \% & $k \cdot 10^{3}, \mathrm{~g} \cdot \mathrm{m}^{-2} \cdot \mathrm{h}^{-1}$ & $\gamma$ & IE, $\%$ \\
\hline- & $16.00 \pm 0.12$ & - & - & $17.10 \pm 0.10$ & - & - \\
\hline$I$ & $16.51 \pm 0.44$ & 0.97 & - & $24.78 \pm 0.52$ & 0.69 & - \\
\hline II & $15.24 \pm 0.40$ & 1.05 & 4.8 & $15.55 \pm 0.60$ & 1.10 & 9.5 \\
\hline III & $7.50 \pm 0.26$ & 2.13 & 53.0 & $6.20 \pm 0.14$ & 2.76 & 63.7 \\
\hline
\end{tabular}

Secondary amine without a substituent in benzene nucleus (I) demonstrates a low intensifying effect, and with the $-\mathrm{OCH}_{3}$ substituent $(\boldsymbol{I I})$ - a low inhibition activity. The strongest effect (corrosion deceleration by 2.13 times) is observed for the compound III with the $-\mathrm{Cl}$ substituent.

The obtained results can be explained with antimicrobial effect of secondary amines on the SRB and their satellites (Figure 1). Thus, compound $\boldsymbol{I}$ is characterized by the smallest spectrum of antibacterial action. It slightly inhibits the development of only one component of the storage culture - IRB (diameter of bacteria growth inhibition zone is $8 \mathrm{~mm}$ ). Compound $\boldsymbol{I I}$ is characterized by wider range of antibacterial effect: it also affects denitrifying bacteria, which under favourable conditions colonize the metal surface first and provide conditions for SRB growth. Its effect on IRB is almost the same as for compound I, and the antibacterial effect on DNB is stronger: the diameter of growth inhibition zone is 1.6 times larger. Compound III inhibits the growth of all the studied enrichment culture components, including SRB - the most aggressive component of the microbial community [1]. In this case, the antibacterial effect on SRB is greater than on 
other bacteria. The diameter of SRB growth inhibition zone is $14 \mathrm{~mm}$. Influence of compound $\boldsymbol{I I I}$ on IRB is stronger than compounds $\boldsymbol{I}$ and $\boldsymbol{I I}$. Influence on DNB is somewhat less than for compound $\boldsymbol{I I}$.

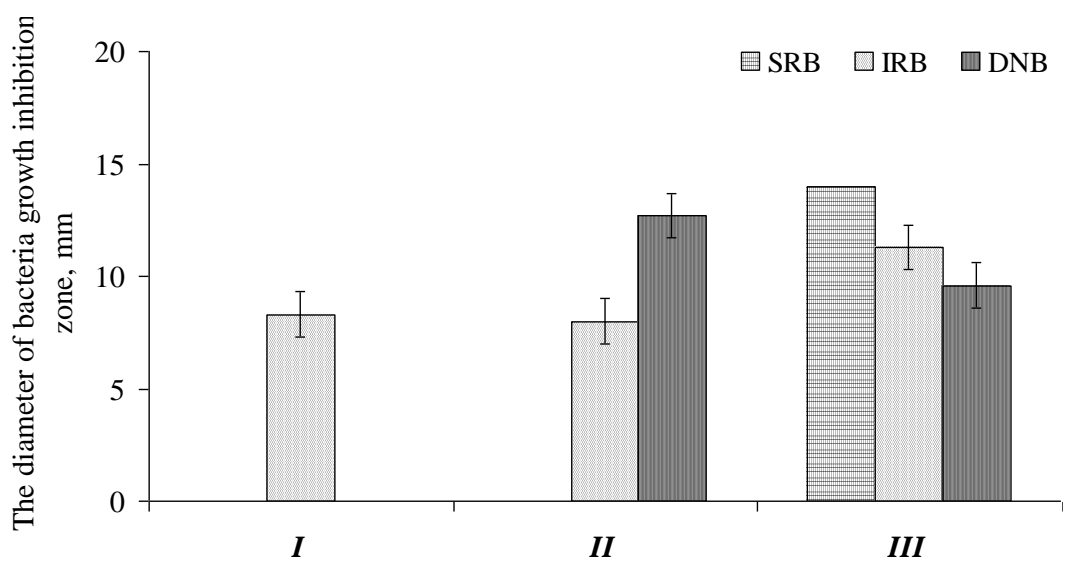

Figure 1. Antimicrobial effect of amines on enrichment culture bacteria.

The effectiveness of the studied secondary amines under microbial corrosion in the Postgate "B" medium, inoculated with strain Desulfovibrio sp. M.4.1 (table 1) is similar to their effect with the presence of the enrichment culture in the corrosive medium. It proves that the effect of the compounds on SRB as component of enrichment culture is dominant during the inhibition of microbial corrosion. It should be noted that the inhibition efficiency of compound $\boldsymbol{I I I}$ is by $10.72 \%$ bigger under the corrosion, initiated by strain Desulfovibrio sp. M.4.1, compared to the enrichment culture at the same concentration.

The effect of the compound concentration on the inhibition efficiency of biocorrosion is insignificant. At the concentration $0.5 \mathrm{~g} / \mathrm{l}$ the inhibition coefficient for compounds $\boldsymbol{I I}$ and III equals 1.08 and 2.09 correspondingly, which means it decreases only by $1.02-1.3$ times.

The data of polarization measurements (Figure 2) is consistent with the results of gravimetry. The intensification of microbial corrosion by compound I is explained with its effect on cathode reaction, in particular, acceleration of cathode process next to stationary potential of the corrosion. Moreover, all the studied compounds shift the free potential of electrochemical corrosion by $40 \mathrm{mV}$ towards positive values.

The morphology of the steel coupons surface after corrosion testing is demonstrated in photos. Numerous SRB colonies can be observed on the steel coupon, which was immersed in the medium without the studied compounds (Figure 3).

On the surface of the coupons, which were immersed in the Postgate "B" medium with compounds I (Figure 4 a) and II (Figure 4 b) the threads of formed polymer matrix can be observed, and in Figure 4c - separate bacteria colonies. 


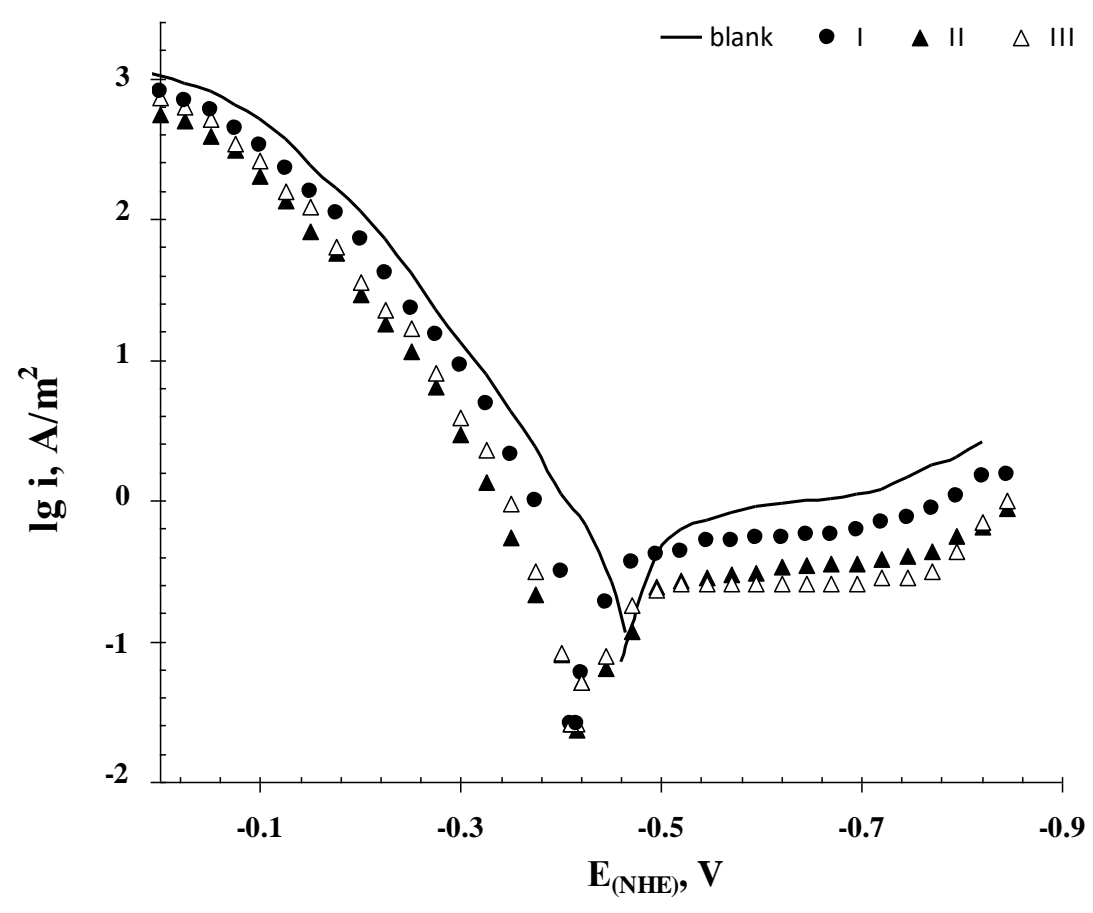

Figure 2. Polarization curves for St3ps steel in water-salt Postgate "B" medium with $0.40 \pm 0.05 \mathrm{~g} / \mathrm{l}$ biogenic $\mathrm{H}_{2} \mathrm{~S}$ (Desulfovibrio sp. M.4.1) in the absence and presence of secondary amine $(0.5 \mathrm{~g} / \mathrm{l})$.

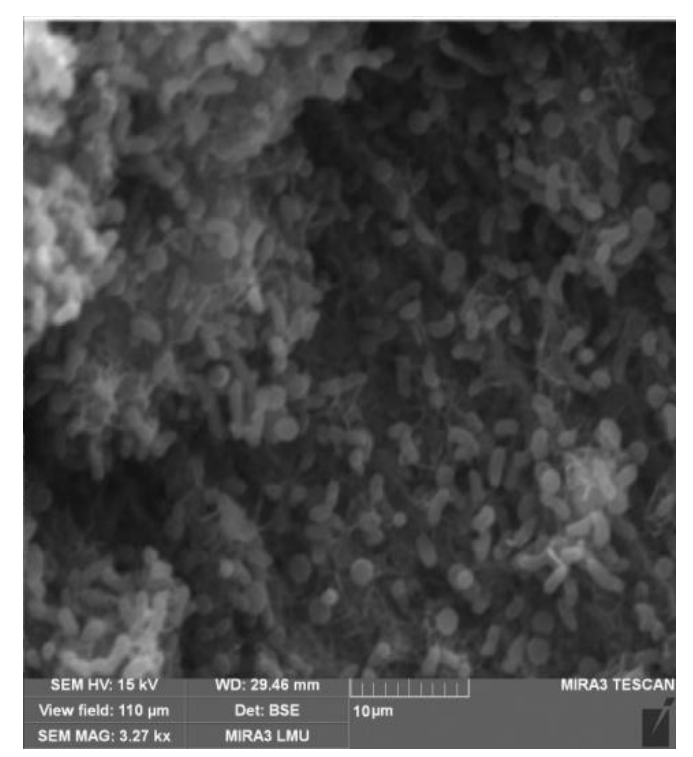

Figure 3. FE-SEM image for the St3ps steel coupon surface after exposure to Postgate "B" medium with strain Desulfovibrio sp. M.4.1 without secondary amines. 

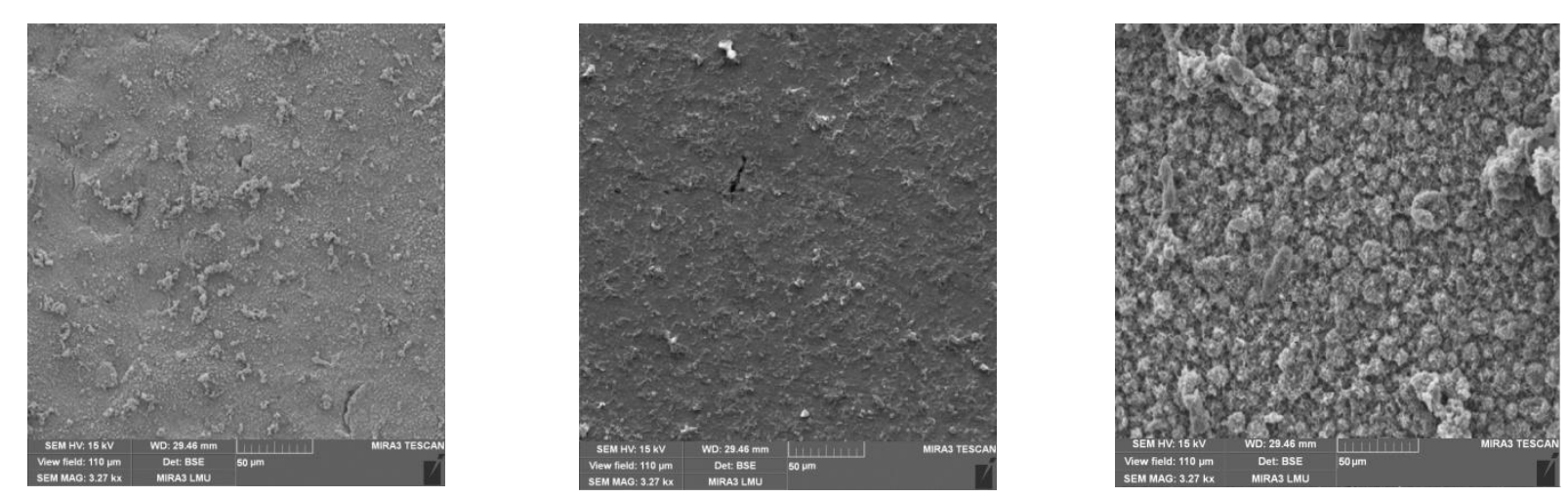

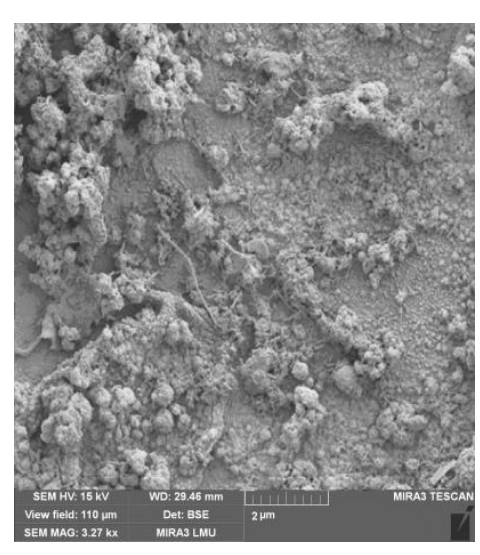

a

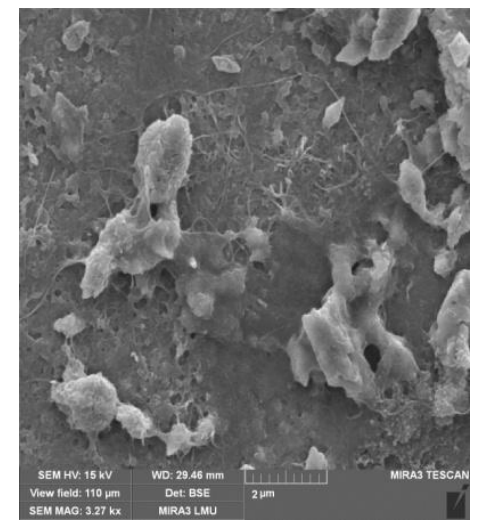

b

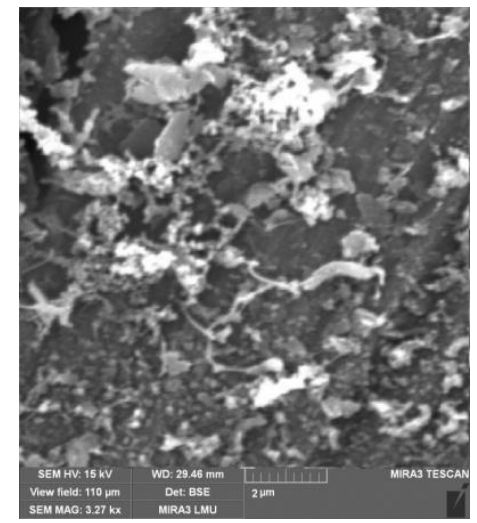

c

Figure 4. FE-SEM images for the St3ps steel coupon surface after exposure to Postgate "B" medium with strain Desulfovibrio sp. M.4.1 and with $0.5 \mathrm{~g} / \mathrm{l}$ secondary amine: $\mathrm{a}-\boldsymbol{I} ; \mathrm{b}-\boldsymbol{I I} ; \mathrm{c}-\boldsymbol{I I I}$.

The results of EDS analysis of the steel coupons surface layers after corrosion tests of the formed biofilm showed that $\mathrm{Fe}$ and $\mathrm{O}$ dominate in the corrosion products (Figure 5). It means that Ferum oxides are the main products of the corrosion. The molar ratio of $\mathrm{Fe}$ to $\mathrm{O}$ is about 7:10 (for $\boldsymbol{I I}$ and $\boldsymbol{I I I}$ ), indicating that the main corrosion products can be either $\mathrm{Fe}_{2} \mathrm{O}_{3}$ or $\mathrm{Fe}_{3} \mathrm{O}_{4}$, or other iron oxides. It can also be stated that the studied secondary amines are able to adsorb on the steel surface under microbial corrosion. This is proven by the presence of Nitrogen, which is the part of elemental composition of substances, in the surface layers; for compound III - the presence of Chlorine. The peculiarity of the elemental composition of surface layers for the compounds $\boldsymbol{I}$ and $\boldsymbol{I I}$ is the presence of $\mathrm{Fe}$ in the areas of energy near $1 \mathrm{keV}$, which indicates the presence of the sulfides of $\mathrm{Fe}_{\mathrm{x}} \mathrm{S}_{\mathrm{y}}$ composition. Such sulfides can perform the function of cathode, accelerating metal corrosion [1].

Thus, without antimicrobial properties the biofilm of the adsorbed compounds neither carries out protective activity, nor prevents the formation of sulfides in the metal surface. 


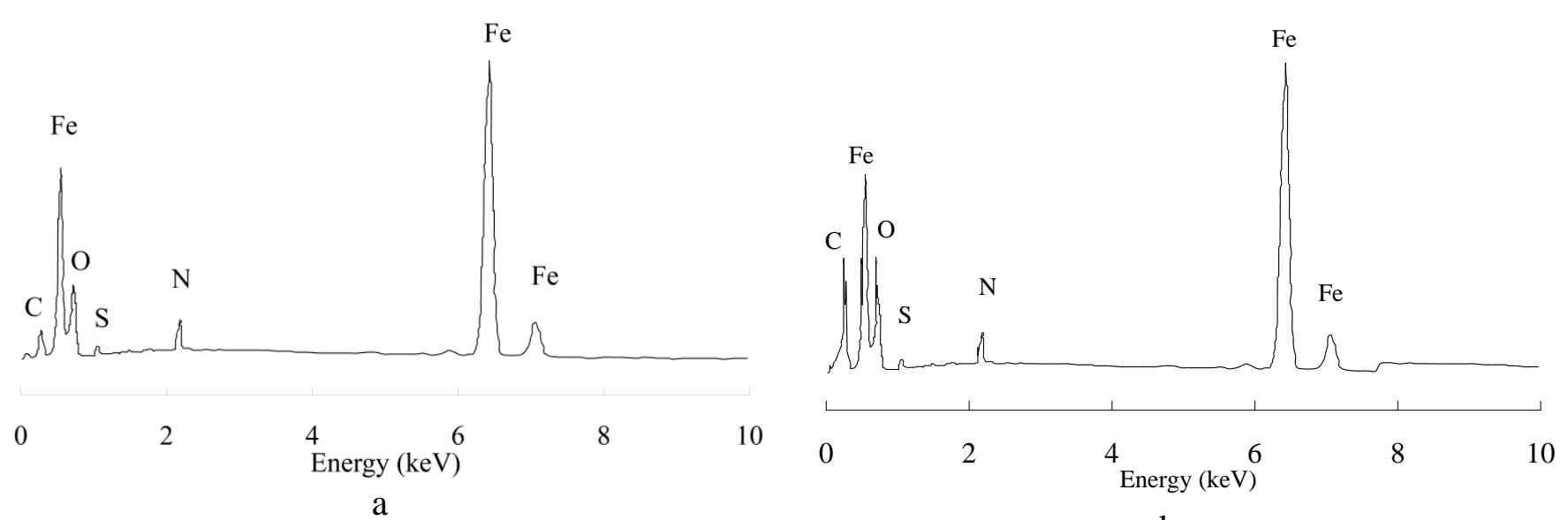

a

b

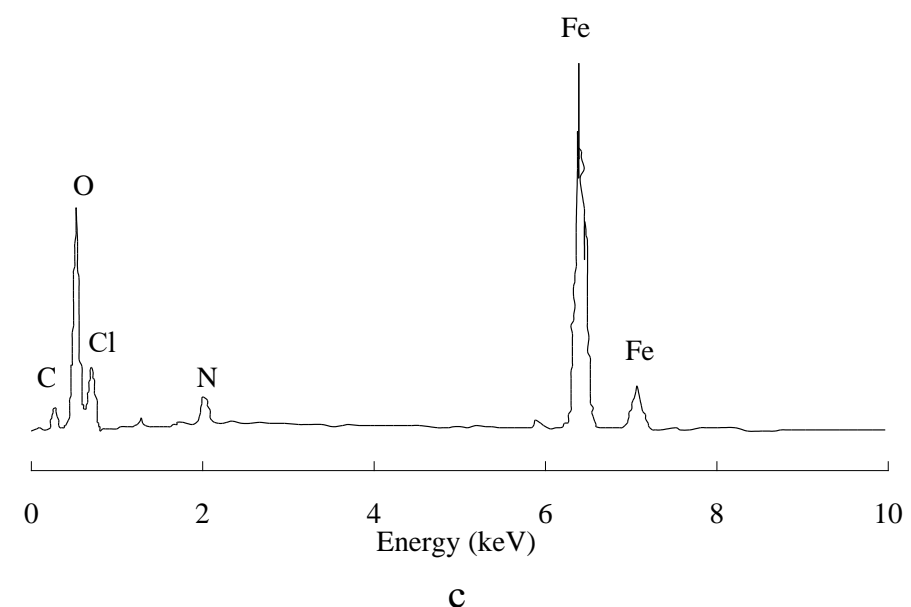

Figure 5. Elemental composition of steel surface layers under the exposure in the inhibited Postgate "B" medium with SRB cultures and compound: a) $\boldsymbol{I}$; b) $\boldsymbol{I I I}$; c) $\boldsymbol{I V}$.

The change of corrosive medium redox potential in time during gravimetric tests also indicates the formation of sulfides (Figure 6).

The main effect on $E$ is caused by the change in hydrogen sulfide concentration. The accumulation of hydrogen sulfide at the beginning of the experiment leads to the shift of redox potential to the negative indices field, which is typical for all the cases. The shift of E index to the positive indices field can be observed for the compound $I$ after 1 day and for compound $\boldsymbol{I I}$ after 2 days, which can be connected with the formation of sulfides with the help of hydrogen sulfide. Moreover, the process is more effective for the compound $\boldsymbol{I}$. After 3 days the redox potential of the corrosive medium decreases gradually because of increase in $\mathrm{H}_{2} \mathrm{~S}$ concentration. In control case (Postgate " $\mathrm{B}$ " medium without secondary amine) and in case with compound $\boldsymbol{I I I}$ redox potential decreases substantially for 2 days, then gradually, which is consistent with the hydrogen sulfide dynamics (Figure 5b). 


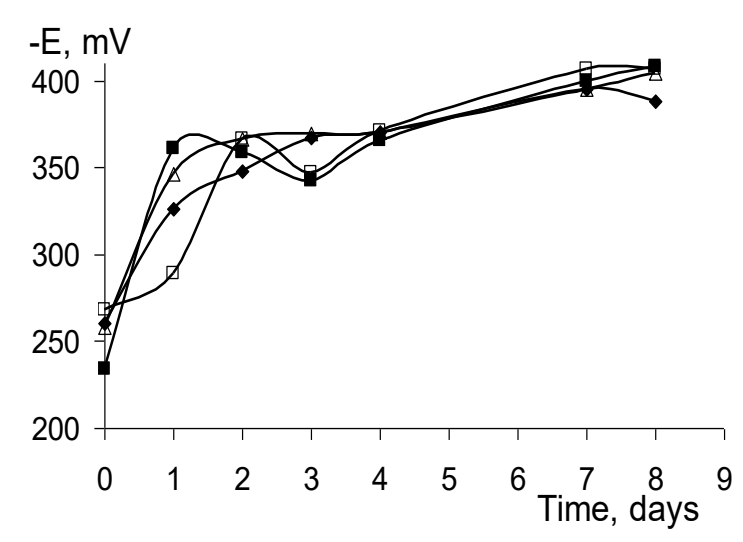

$\mathrm{a}$

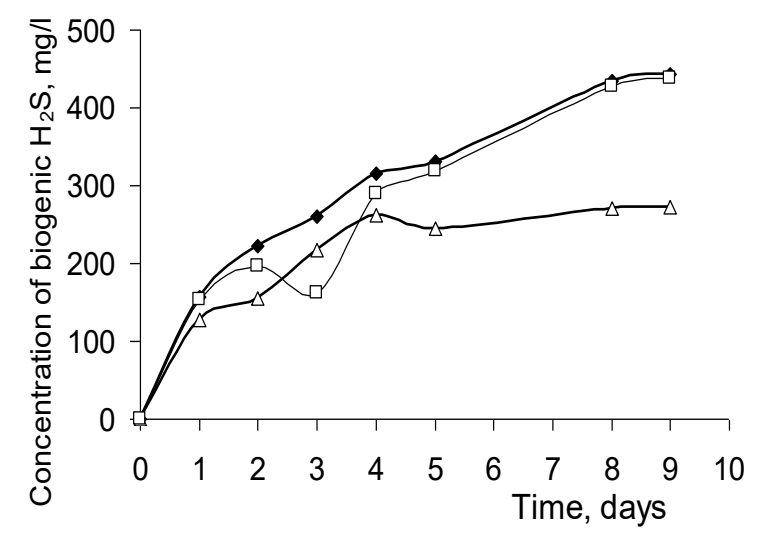

b

$\rightarrow$ without secondary amine $\rightarrow-1+\mathrm{II} \triangle \mathrm{III}$

Figure 6. Change in time of the microbial steel Sp3ps corrosion indices in the Postgate "B" medium with strain Desulfovibrio sp. M.4.1 (compound concentration $0.5 \mathrm{~g} / \mathrm{l}$ ):

a) redox potential; b) concentration of biogenic hydrogen sulfide.

\section{Conclusions}

Secondary amines with cyclic substituents of different nature are able to adsorb on mild steel surface under microbial corrosion with bacterial sulfate reduction. The inhibition effect is ensured only in case of adsorption of compounds, which have antimicrobial properties against sulfate reducing bacteria.

\section{Acknowledgements}

Authors are especially grateful to N.R.Demchenko for the provided strain Desulfovibrio sp. M.4.1, which was used in the study.

\section{References}

1. I. Kozlova, O. Radchenko, L. Stepura, T. Kondratuk and A. Pilyashenko-Novohatnyj, Heokhimichna Diyalnist Mikroorganizmiv ta ii Prykladni Aspekty (Geochemical activity of microorganisms and its applied aspects), Naukova dumka, Kiev, 2008, p. 528 (in Ukrainian).

2. T.A. Onat, D. Yiğit, H. Nazır, M. Güllü and G. Dönmez, Int. J. Corros. Scale Inhib., 2016, 5, no. 3, 273. doi: 10.17675/2305-6894-2016-5-3-7

3. Yu.V. Golyak and S.M. Beloglazov, Praktika protivokorrozionnoy zashchity, 2001, 1, no. 19, 11 (in Russian).

4. A.N. Zavershinskii and V.I. Vigdorovich, Vestnik Tambovskogo universiteta. Seriya: Estestvennyye i tekhnicheskiye nauki, 2000, 5, no. 1, 25 (in Russian). 
5. V.I. Vigdorovich, A.N. Zavershinskii, L.E. Tsygankova, T.N. Nazina, M.N. Esina and N.V. Shel, Int. J. Corros. Scale Inhib., 2017, 6, no. 1, 1. doi: 10.17675/2305-68942017-6-1-1

6. N.M. Agayev, Fiziko-khimicheskaya mekhanika materialov, 2000, 1, 572 (in Russian).

7. N. Demchenko, I. Kurmakova, O. Gumenjuk and O. Tretjak, Fizyko-khimichna mehanika materialiv, 2008, 7, 538. (in Ukrainian).

8. I. Kurmakova, O. Bondar, S. Polevichenko and N. Demchenko, Chem. Chem. Technol., 2017,11 , no. $3,314$.

9. S.V. Pryhod'ko, I.M. Kurmakova, N.R. Demchenko and O.P. Tretjak, Fizykokhimichna mehanika materialiv, 2006, 5, 919. (in Ukrainian).

10. I.N. Kurmakova and S.V. Prikhodko, Ekotekhnologii i resursosberezhenie, 2007, 2, 16 (in Russian).

11. A.M. Demchenko, K.G. Nazarenko, A.P. Makey, S.V. Prikhodko, I.N. Kurmakova and A.P. Tretyak, Zhurnal prikladnoy khimii, 2004, 77, no. 5, 794 (in Russian).

12. S.V. Prihod'ko, I.M. Kurmakova and O.P. Tretjak, Mikobiologichny zhurnal, 2007, 69, no. 6, 26 (in Ukrainian).

13. N.R. Demchenko, I.M. Kurmakova and O.P. Tretyak, Mikrobiologiya $i$ biotekhnologiya, 2013, 4, 90 (in Ukrainian).

14. N.S. Egorov, Rukovodstvo $k$ praktycheskym zanjatyem po mykrobyologhyy (Guide to practical work on microbiology), Moscow University, Moscow, 1983, p. 224 (in Russian).

15. M.N. Fokin and K.A. Zhigalova, Metody korrozionnyh ispytanij metallov (Methods of corrosion testing of metals), Metallurgiya, Moscow, 1986, p. 80 (in Russian).

16. J.R. Postgate, The sulfate reducing bacteria, 2nd. ed., Cambridge University Press, Cambridge, 1984, p. 151.

17. C. Xua, Y. Zhanga, B. Chenga and W. Zhub, Mater. Charact., 2008, 59, no. 3, 245. doi: 10.1016/j.matchar.2007.01.001 